\title{
Evaluation of the Need for Apron Area in Sultan Babullah Ternate Airport Development Plan.
}

\author{
Muhammad Rizal*, Muhammad Darwis, and Miranda Ilham \\ Department of Civil Engineering, Faculty of Engineering, Khairun University, Ternate North Maluku
}

\begin{abstract}
This research method was carried out by using data retrieval, namely flight data for the last five years, after which retrieval data for existing conditions, then proceed to the calculation of forecasting longterm air traffic growth, namely the next 20 years, forecasting air traffic growth for the next 20 years needs to be done to calculate the apron capacity due to forecasting an increase in the total number of aircraft movements in the apron in future. With the development of the apron to meet the needs of air traffic, the results of the analysis of the calculation of peak hours get the number of aircraft movements in the peak hours of 2039 by 14 movements, knowing the number of aircraft movements based on its class to get aircraft movements at peak hours, you get the need for a parking stand in tofu. 2039 as many as 13, the planned year 2039 with the addition of the number of parking stands by 13, then the addition of taxiways based on the forecasting results of parking stands in 2020 to 2039, it is known that the dimensions of the parking lot in 2039 for the apron are $187 \mathrm{~m}$ long and $83 \mathrm{~m}$ wide with an area. $15,621 \mathrm{~m}^{2}$.
\end{abstract}

Keywords : Air Traffic, Peak Hours, Forecasting

\section{Introduction}

Flight is one of the other modes of transportation that cannot be separated from other transportation modes that are handled in the national transportation system, which is dynamic which is able to adapt to future advances and has the ability to reach the destination in fast time, high technology and requires a level of safety both in aircraft conditions and conditions of various infrastructure at the airport.

The current development development in Ternate City is in full swing to fix and improve existing infrastructure facilities, especially in the field of tourism. Sultan Babullah Airport is located in Tafure Village, Ternate City, North Maluku Province, approximately $6 \mathrm{~km}$ north of Ternate City. Therefore, the city of Ternate is very dependent on-air transportation, it is necessary to improve the supporting facilities of the airport, one of which is the apron and the number of aircraft currently operating is only ATR 72500, ATR 72-600, and Boeing 737-800 Airbass A320 / 200 so it is necessary to improve service capabilities in order to meet community demand and participate in supporting the growth and development of the city.

The development of Sultan Babullah Airport which will be planned as an apron, a calculation that refers to the International Civil Aviaton Organization (ICAO) standard with the Boeing 737-900 plan aircraft, requires a runway length of 2,400 meters wide 51 meters and the distance between the runway and sumbuh.
The connecting runway is 170 meters, the total width of the taxiway is 25 meters, with a flexible pavement thickness of $70 \mathrm{~cm}$, an apron area of $180 \times 90=16,200$ $\mathrm{m} 2$, the thickness of the rigid pavement on the Federal Aviation Administation Method (FAA) apron $=35 \mathrm{~cm}$. The apron can only accommodate several types of aircraft.

With the increase in demand for air transportation, of course, this results in an increase in passengers which affects the number of aircraft movements which are related to the number of flights carried out. The position and capacity of the apron is very important at the airport because it is one that determines the smooth running of airport activities. So it can be concluded and it is necessary to evaluate the needs of the apron and regarding the performance of the use of the apron for the next few years in order to get the right solution to address the increasing need for aircraft.

\section{Fundamental Theory}

\subsection{Airport Planning}

Airport is an airfield used for landing and taking off aircraft disembarking passengers, loading and unloading cargo, and equipped with aviation safety facilities and as a place for intermodal transfer [1]. Airside facilities of an airport include the runway (runway), connecting runway (taxiway), and the area of the aircraft parking lot

\footnotetext{
* Corresponding author : adams.rizal@yahoo.co.id
} 
(apron), the dimensions of the runway, taxiway, and apron depending on the type and characteristics of the aircraft [2].

\subsection{Aircraft Characteristics}

Before designing the development of an aerodrome, it requires knowledge of the characteristics of an airplane in general to plan its infrastructure. Aircraft characteristics include :

1. Size of the aircraft determines the runway width, taxiway width, and apron.

2. The weight of the aircraft determines the thickness of the runway, taxiway and apron pavement.

3. Passenger capacity has an effect in determining facilities in and around the airport terminal.

4. The need for apron dimensions affects the required Bandar ayang land area.

\subsection{Forecasting Air Traffic Growth Using Econometrik Methods}

The most sophisticated and complex technique in forecasting is the use of econometric models. Econometric models relate to the size of flight activity on economic and social factors that influence future forecasting techniques. There are a wide variety of techniques used in econometric modeling for airport planning :

1. Trip generation and gravity modeling are quite common in forecasting passenger and aircraft traffic.

2. Simple and multiple regression analysis techniques, either linear or non-linear, are often applied to various kinds of forecasting problems to ensure between the static variables and the explanatory variables. The form of the equation used in multiple linear regression analysis is given in the equation according to FAA:

$$
\begin{array}{r}
\text { Yest }=a 0+a 1+x 1+a 2 \cdot x 2+x 3 \\
+a 3 \ldots+a n \cdot X n \text { (1) }
\end{array}
$$

\subsection{Calculation of Peak Hour}

Calculation of peak hour volume in this study is needed as a basis reference to the maximum condition for using the apron. This is to determine the maximum movement rate during peak hour conditions. Based on existing data, the average daily movement rate on the apron in one year and the number of aircraft movements on the apron during the peak month of the year. It can be seen the ratio of the total number of aircraft movements a year [3].

$$
\mathrm{R} \text { month }=\frac{N \text { mont }}{N \text { year }}
$$

\subsection{Air Side Facilities}

In principle, an airport must have airside facilities such as arunway, which is a pavement used by an airplane to land (take off) and take off (landing)(4).

At airports that must be considered are the length, number, width, distance to the taxiway and parking lot (apron), and the orientation of the runway to the wind.

\section{Methodology Of Research}

Data collection that the author does is by using secondary data collection which is obtained directly from the relevant agencies, namely at Sultan Babullah Tenate Airport. After taking the data that will be used at this data collection stage, namely: The

1. Type of aircraft and its characteristics operated at Sultan Babullah Tenate Airport in the last 5 years and an estimate for the next 20 years.

2. Apron Specifications Sultan Babullah Ternate Airport.

3. Total air traffic volume and number of aircraft movements in the last 5 years.

4. Flight schedule at Sultan Babullah Ternate Airport. After searching the data for the existing conditions, it is continued to the calculation of long-term air traffic growth forecasting, namely the next 20 years. It is necessary to forecast the growth of air traffic for the next 20 years to calculate the apron capacity due to forecasting the increase in the number of total aircraft movements in the apron in the future.

Planning for Parking Platform Dimensions (Apron). At this stage in planning the dimensions of the apron in accordance with existing airport regulations. To plan the dimensions of the apron, the points that must be considered are as follows:

1. Number of gate positions

2. Type of aircraft Aircraft

3. Movement Aircraft

4. Parking system Based on the number of requirements for the position of the gate, it will be known the need for the parking take-off dimension (apron) of Sultan Babullah Ternate Airport.

\section{Result and Discussions}

\subsection{Movement Growth Forecasting}

In this calculation, the distribution of aircraft departure movements in the planning year will be obtained based on historical data from 2015-2019. From the distribution of flight departures, the number of aircraft movements will be obtained during peak hour.

\subsection{Analysis of Aircraft Movement Existence aircraft}

Based on movement data at Sultan Babullah Ternate Airport in 2015-2019 which will be used is shown in the following table. 
Table1. Aircraft Movement Data 2015-2019

\begin{tabular}{|r|c|r|r|r|}
\hline \multirow{2}{*}{ NO } & \multirow{2}{*}{ YEAR } & \multicolumn{2}{|c|}{ AIRCRAFT } & \multirow{2}{*}{ TOTAL } \\
\cline { 3 - 4 } & & ARRIVED & DEPARTURE & \\
\hline 1 & 2015 & 5.728 & 5.728 & 11.456 \\
\hline 2 & 2016 & 5.669 & 5.669 & 11.338 \\
\hline 3 & 2017 & 5.696 & 5.696 & 11.392 \\
\hline 4 & 2018 & 5.773 & 5.773 & 11.546 \\
\hline 5 & 2019 & 4.523 & 4.523 & 9.046 \\
\hline \multicolumn{4}{|c|}{ TOTAL } & 54.778 \\
\hline
\end{tabular}

Source : Airport Flight Unit (UPBU)

Table 1 presents information relating to aircraft movements from 2015 2019. Data on aircraft movements are distinguished between arrival data (Arr) and departure data (Dep). The example in circle 5,728 shows the number of aircraft arrivals in 2015, while 5,728 shows the number of aircraft departures in 2015 . Accumulated per year, the data in Table 1 is presented in Figure 1.

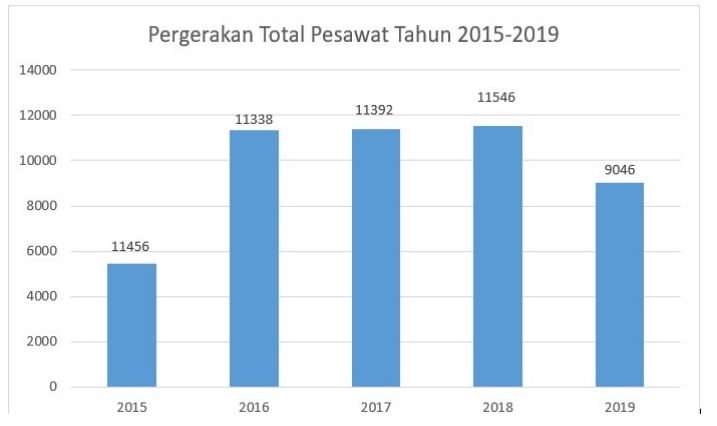

Fig.1. Graph of Total Aircraft Movement in 2015-2019

\subsection{Apron}

The apron is a vital place for the continuity of the movement of aircraft other than the runway. Because in this apron the meeting place for movements between passengers and aircraft where the aircraft is parked and carries out all its activities until the plane is ready to leave for its destination [5]. Likewise with passengers, the apron is a place where passengers can get on and off the plane.

At Sulatan Babullah Ternate Airport, it has a parking area with the following dimensions:

Total Parking $=7$ aircraft ( 4 wide bodies and 3 narrow bodies)

$$
\text { Area } \quad=16,200 \mathrm{~m} 2
$$

The apron layout must be planned by taking into account the characteristics of the aircraft using the apron such as width the wings, length and turning radius of the aircraft, as well as the area required by the vehicles that provide service to the aircraft while on the apron.

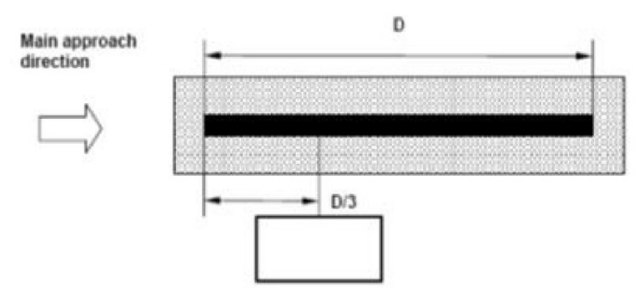

Fig. 2. Apron Layout

Position of Apron $=1 / 3 \mathrm{D}$

Where :

D : Length ofRunway

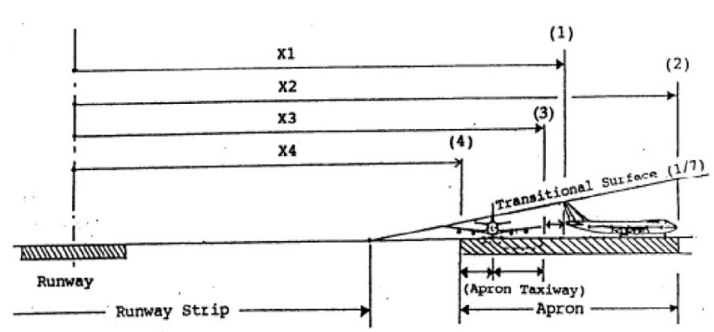

(Source : SKEP 77-VI-2005 Director General of Transportation)

Fig.3. Position of Apron and Taxiway

Each position is in the airplane park from the runway center line arranged as follows :

$\mathrm{X} 1=$ maximum position from the tail of the aircraft to the runway centerline.

$\mathrm{X} 2=$ Position from runway center line to terminal building. ( $\mathrm{X} 2=\mathrm{X} 1+$ the maximum length of the aircraft)

$\mathrm{X} 3$ = The position of the wing tip of the aircraft which is on the side of the terminal building to the center line of the runway. (X3 = X1 - distance between two planes) $\mathrm{X} 4=$ position of the end of the plane park to the runway center line (X4 = X3 - Maximum aircraft width / 2)

Table 2. Free Distance Between Aircraft in apron

\begin{tabular}{|l|c|c|c|c|c|c|}
\hline \multirow{2}{*}{ DESCRIPTIONS } & \multicolumn{5}{|c|}{ CODE LETTER } \\
\cline { 2 - 7 } & $\mathrm{A} / \mathrm{I}$ & $\mathrm{B} / \mathrm{II}$ & $\mathrm{C} / \mathrm{III}$ & $\mathrm{D} / \mathrm{IV}$ & $\mathrm{E} / \mathrm{V}$ & $\mathrm{F} / \mathrm{VI}$ \\
\hline $\begin{array}{l}\text { The clearance between } \\
\text { a parked aircraft and a } \\
\text { plane about to take off }\end{array}$ & 10 & 10 & 10 & 15 & 15 & 15 \\
\hline $\begin{array}{l}\text { Clearance between } \\
\text { parked aircraft and } \\
\text { aircraft on taxilines } \\
\text { and other } \\
\text { obstructions }\end{array}$ & 4.5 & 4.5 & 7.5 & 7.5 & 10 & 10 \\
\hline $\begin{array}{l}\text { The distance of aircraft } \\
\text { was walking with the } \\
\text { aircraft in the lead-in } \\
\text { line and other aircraft }\end{array}$ & 4.5 & 4.5 & 7.5 & 7.5 & 10 & 10 \\
\hline $\begin{array}{l}\text { The distance between } \\
\text { parallel planes on the } \\
\text { apron and other } \\
\text { buildings }\end{array}$ & 4.5 & 4.5 & 7.5 & 7.5 & 10 & 10 \\
\hline $\begin{array}{l}\text { Distance between } \\
\text { aircraft with refueling } \\
\text { and building }\end{array}$ & 15 & 15 & 15 & 15 & 15 & 15 \\
\hline
\end{tabular}




\section{Conclusion}

Based on the results of the analysis, it is concluded that the calculation of the peak hours obtained for aircraft movements in 2039 is 14 movements. After getting the aircraft movement at peak hours, it can be seen that the need for parking stands in 2039 is 13 and the dimensions of the parking space for the apron are $187 \mathrm{~m}$ long and 83 $\mathrm{m}$ wide with an area of $15,621 \mathrm{~m} 2$.

Authors would like to gratefully acknowledge the Ministry of Research, Technology and Education of Indonesia for supporting fund of the Competitive Research of Higher Education, Khairun University in 2021 Authors like also thanks to the Department of Civil Engineering, Engineering Faculty, Khairun University for supporting this research.

\section{References}

[1] D. General and P. Air, "Skep 76-Vi-2005," (2005).

[2] H. Basuki, Designing and Planning Airfields. (2008).

[3] H. Muhammad, "Final Project Evaluation of Air Side Facilities for Syamsudin Noor Banjarmasing in Facilitating the Growth of Aircraft Movement. Sepulu Nopember Institute of Technology, "2016.

[4] W. Sartono, “ Airport Introduction and Geometric Design of Runways, Taxiways and Aprons., "2016.

[5] N. Muhammad, "Evaluation of Apron Area Needs in Airport Development Plans International Ahmad Yani Semarang., "2016. 